
World Ecology

\title{
The state of the atmosphere in the city of Krasnoyarsk (Russia) in indicators of sustainable development
}

\section{N. Shaparev, A. Tokarev \& O. Yakubailik}

To cite this article: N. Shaparev, A. Tokarev \& O. Yakubailik (2019): The state of the atmosphere in the city of Krasnoyarsk (Russia) in indicators of sustainable development, International Journal of Sustainable Development \& World Ecology, DOI: 10.1080/13504509.2019.1699879

To link to this article: https://doi.org/10.1080/13504509.2019.1699879

曲 Published online: 08 Dec 2019.

Submit your article to this journal $๘$

LII Article views: 36

Q View related articles ¿

View Crossmark data \lceil 


\title{
The state of the atmosphere in the city of Krasnoyarsk (Russia) in indicators of sustainable development
}

\author{
N. Shaparev (iD) ${ }^{a, b, c}, A$. Tokarev (DD ${ }^{a}$ and O. Yakubailik (D) ${ }^{a, b}$ \\ anstitute of Computational Modeling SB RAS, Krasnoyarsk, Russia; 'bSiberian Federal University, Krasnoyarsk, Russia; 'National Research \\ Tomsk State University, Tomsk, Russia
}

\section{ABSTRACT}

The article deals with the state of the atmosphere of Krasnoyarsk (Russia) over the period 2007-2017 in the indicators of sustainable development adopted by the UN, developed in the USA and Russia. For this purpose, data from annual State reports on the state of the environment and recordings from automated city monitoring stations are used. The dynamics of gross emissions of pollutants into the city atmosphere, the annual state of air quality and air quality in real time in 2018 are analyzed. The dependence of the Air Quality Index on weather conditions is investigated.

\section{ARTICLE HISTORY}

Received 14 October 2019

Accepted 26 November 2019

\section{KEYWORDS}

Atmosphere; Krasnoyarsk; sustainable development; AQI; $\mathrm{PM}_{2.5}$

\section{Introduction}

The atmospheric air is an essential component of the environment. Industrial activity generates large quantities of pollutants emitted into the atmosphere, which both degrades the quality of atmospheric air near the source of pollution, causing local environmental problems, and affects the overall environmental processes. According to the World Health Organization (WHO), about 7 million people died from air pollution worldwide in 2012 (WHO 2014). This result is about twice as high as the previous estimates (WHO 2009) and confirms that air pollution nowadays is the world's largest environmental health risk.

The problem of urban air pollution is widely known in the world. The most appropriate and economically feasible policy measures to reduce particulate matter and ozone are explored in Israel (Lavee 2018); in China effective measures to combat air pollution are developed $\mathrm{Hu}$ 2006; Bell et al. 2011; Niu et al. 2013) and the impact of urban air pollution on urban ecosystems is investigated (Shi et al. 2018); concentrations of the major air pollutants. In London and Moscow are compared (Zvyagintsev et al. 2014). The first occurrence of smog was recorded over London in December 1952, which resulted from the burning of coal (Bell et al. 2004). In today's situation, smog occurs in many cities around the world.

According to the State report on the state and protection of the environment (SR 2018), the total volume of emission of pollutants into the air in Russia as a whole in 2017 has changed slightly compared to 2010 (a decrease of $1 \%$ ). Since 2012, there has been a redistribution of emissions: emissions from stationary sources have dropped by $11 \%$ while those from mobile sources have increased by $14 \%$. Among the subjects of administrativeterritorial division in Russia, the largest volume of emissions from stationary sources has been registered in the
Siberian Federal District (SFD), which in 2017 amounted to 5762.4 thousand tonnes (33\% of the all-Russian indicator).

This paper describes the state of the atmosphere in Krasnoyarsk (SFD) in terms of sustainable development based on the analysis of data presented in the State reports 'On the state and protection of the environment in the Krasnoyarsk territory' (MEEM 2008-2018) for the period from 2007 to 2017, and data for 2018 from automated monitoring posts located in the city.

\section{Object of research}

Krasnoyarsk was founded by Russian Cossacks in 1628 . They chose a place in the valley of the Yenisei River partly framed by mountain ranges to protect them from winds. Later, the so-called Moscow Highway, a state route connecting the central part of Russia with its Far Eastern regions, passed through Krasnoyarsk. In 1832, Krasnoyarsk became the administrative center of the Yenisei Province. The favorable geographical location and availability of rich natural resources predetermined (since 1934) the intensive development of chemical, metallurgical, pulp and paper, machine-building, fuel and energy industries in the city, which eventually led to a large amount of atmospheric emissions. The situation worsened in the 1990s for the reason of sharp increase in the number of imported used cars. Being protected against winds further aggravated the ecological situation to result in occasional appearance of smog in the city. Currently, the city is located on both banks of the Yenisei, extending for $25 \mathrm{~km}$ along the river, and for about $10 \mathrm{~km}$ in the transverse direction. According to the Federal state statistics service for the Krasnoyarsk 
territory (Krasnoyarskstat) for 2018, the city's population is about 1 million.

The relief features and local climatic conditions in the area of Krasnoyarsk are responsible for the unfavorable weather conditions. These circumstances increase the concentration of substances emitted by stationary industrial enterprises and mobile sources (vehicles) in the atmosphere of the city. Accumulation of particulate matter in the atmosphere leads to smog over the city and deterioration of the living conditions of its population.

According to the 2018 data (SR 2018), Krasnoyarsk has been included in the priority list of 20 Russian cities with the highest level of air pollution. The amount of pollutants per year emitted by stationary sources of pollution in Krasnoyarsk is 629 thousand tonnes, $81.3 \%$ of which is captured, and $42.2 \%$ of them are utilized.

The following industrial enterprises of Krasnoyarsk produced the highest emission of pollutants into the atmosphere in 2017: JSC 'RUSAL Krasnoyarsk' - up to 56.8 thousand tonnes, Krasnoyarsk Thermal Power Plant (TPP)-1 - 17.0 thousand tonnes, Krasnoyarsk TPP-2 14.0 thousand tonnes, Krasnoyarsk TPP-3 - up to 9.6 thousand tonnes. According to the reported data as of 26 May 2017, the number of registered motor vehicles and trailers was about 411 thousand units.

\section{Research methods and tools}

To study the state of the atmosphere, we employ the UN sustainable development indicators (UN 1996) as well as the indicators developed in individual countries of the world. Earlier we used the UN indicators to analyze water resources for the city of Krasnoyarsk (Shaparev and Astafiev 2008).

\subsection{UN sustainable development indicators for the atmosphere}

The UN indicators of sustainable development for atmospheric air protection encompass the following parameters:

- Input Influence

- Greenhouse gas emissions $\left(\mathrm{CO}_{2}, \mathrm{CH}_{4}, \mathrm{~N}_{2} \mathrm{O}\right)$; measured in gigagrams/year.

- Sulphur oxide $\left(\mathrm{SO}_{\mathrm{x}}\right)$ emissions; measured in tonnes/year per person.

- Emissions of nitrogen oxides $\left(\mathrm{NO}_{\mathrm{x}}\right)$; measured in tonnes/year per person.

- Consumption of ozone-depleting substances; measured in tonnes per year.

- Conditions

- Concentration of pollutants in the city atmosphere $\left(\mathrm{O}_{3}, \mathrm{CO}, \mathrm{PM}, \mathrm{SO}_{2}, \mathrm{NO}_{2}, \mathrm{NO}\right)$; measured in $\mathrm{mg} / \mathrm{m} 3$.

- Management

- Air pollution abatement costs; measured in USD.

\subsection{Maximum permissible concentrations of matter in the atmosphere for Russia}

Currently, sanitary and hygienic standards focused on human health indicators are of crucial importance for the control and management of environmental quality in Russia. This group includes standards of maximum permissible concentrations (MPC) of harmful matter in the air.

As a rule, there are 2 regulatory levels for pollutants:

- Regulatory level for a short-term exposure to pollutants, defining the 'maximum single maximumpermissible concentration' (MPC $\mathrm{MS}_{\mathrm{MS}}$ ). This concentration, when inhaled for 20-30 min, should not cause any reflex reactions in the human body.

- Regulatory level for a long-term exposure (8 h, 24 h, and up to 1 year for some pollutants). In the Russian Federation, this regulatory level is set for $24 \mathrm{~h}$ and is called 'maximum permissible average daily concentrations' $\left(M P C_{A D}\right)$. This concentration should not cause any direct or indirect harmful effects to humans if inhaled for an indefinite period (years)

Maximum permissible concentrations of major pollutants in the Russian Federation are given in Table 1.

\subsection{Air pollution indices in Russia}

The Standard Index (SI) is the highest measured single pollutant concentration divided by MPC; it is determined from observations of one pollutant at one monitoring post or all pollutants at all posts of the area over a month or a year.

The Highest Repeatability (HR) is the percentage of exceeding the MPC according to observations at one post (for one pollutant) or at all posts of the district for all pollutants over a month or a year.

The Air Pollution Index (API) describes the concentration of pollutants in fractions of $M P C_{A D}$. In practice, two indices of air pollution are used: API for each pollutant and the integrated indicator API-5, which takes into account air pollution for five priority pollutants for the city (RD 1991). The indices characterize the level of air pollution over a specific period.

Table 1. MPC values for pollutants $(\mathrm{mg} / \mathrm{m} 3)$.

\begin{tabular}{lccccc}
\hline Pollutant & $\begin{array}{c}\text { Effective } \\
\text { date }\end{array}$ & $\mathrm{MPC}_{\mathrm{MS}}$ & $\mathrm{MPC}_{\mathrm{AD}}$ & $\mathrm{MPC}_{\mathrm{YEAR}}$ & $\begin{array}{c}\text { Hazard } \\
\text { class }\end{array}$ \\
\hline Nitrogen dioxide & 29.04 .1998 & 0.085 & 0.04 & & 2 \\
& 01.02 .2006 & 0.2 & 0.04 & & 3 \\
Sulfur dioxide & 29.04 .1998 & 0.5 & 0.05 & & 3 \\
Carbon monoxide & 29.04 .1998 & 5 & 3 & & 4 \\
Ozone & 29.04 .1998 & 0.16 & 0.03 & & 1 \\
Benzopyrene & 29.04 .1998 & - & $10^{-6}$ & & 1 \\
$\mathrm{PM}_{10}$ & 19.04 .2010 & 0.3 & 0.06 & 0.04 & - \\
$\mathrm{PM}_{2.5}$ & 19.04 .2010 & 0.16 & 0.035 & 0.025 & - \\
Formaldehyde & 29.04 .1998 & 0.035 & 0.003 & & 2 \\
& 25.07 .2014 & 0.05 & 0.01 & & 2 \\
\hline
\end{tabular}


Calculation of API is based on the assumption that all harmful pollutants at the MPC level have the same effect on a human, and with growing concentration, the degree of their harmfulness increases at a different rate depending on the hazard class of the substance. The API value for a single pollutant $l i$ and the integrated API indicator for $\mathrm{m}$ pollutants $\mathrm{I}(\mathrm{m})$ are calculated by the formulas (1):

$$
l_{i}=\left(\frac{q_{i}}{M P C_{i}}\right) K_{i}, \quad I(m)=\sum_{i=1}^{m}\left(\frac{q_{i}}{M P C_{i}}\right) K_{i}
$$

where qi is the average annual concentration of the $i$-th pollutant; $M P C_{i}$ is its maximum permissible average daily concentration; $K_{i}$ is a dimensionless coefficient showing the degree of hazard of the $\mathrm{i}$-th pollutant compared to sulfur dioxide. $\mathrm{K}_{\mathrm{i}}=0.85 ; 1.0$; $1.3 ; 1.5$ for the 4-, 3-, 2 - and 1 - class hazard of the substance, respectively.

API values of $\mathrm{I}_{\mathrm{i}}<5$ correspond to a low pollution level, $5<\mathrm{I}_{\mathrm{i}}<8$ - increased pollution, $8<\mathrm{I}_{\mathrm{i}}<15$ - high pollution, and $\mathrm{I}_{i} \geq 15$ means a very high degree of air pollution.

\subsection{US air quality index}

For an integrated assessment of the degree of air pollution many countries of the world use unified indicators - indices of atmospheric quality. The most common among them is the Air Quality Index (AQI), developed by the US Environmental Protection Agency (EPA 2018). This is the easiest and informative way to understand the environmental situation as it can provide information on air pollution to the public in a simple and visual manner. AQI can take on values from 0 to 500; the higher its value, the higher the level of air pollution and the greater the health hazard. The scale of values is divided into a number of categories (Table 2): Good, Moderate, Unhealthy for Sensitive Groups, Unhealthy, Very Unhealthy, and Hazardous.

$A Q I$ definition is based on the concentrations of several pollutants, such as particulate matter with a diameter of less than $10 \mu \mathrm{m}\left(\mathrm{PM}_{10}\right)$ and less than $2.5 \mu \mathrm{m}\left(\mathrm{PM}_{2.5}\right)$, carbon monoxide $\mathrm{CO}$, sulfur dioxide $\mathrm{SO}_{2}$, nitrogen dioxide $\mathrm{NO}_{2}$ and ozone $\mathrm{O}_{3}$. This index is calculated sequentially for each pollutant using the piecewise linear interpolation formula (EPA 2018):

$$
\begin{aligned}
& A Q I=\frac{I_{\text {high }}-I_{\text {low }}}{C_{\text {high }}-C_{\text {low }}}\left(C-C_{\text {low }}\right)+I_{\text {low }}, \\
& A Q I^{*}=\max _{k}\left[A Q I_{k}\right]
\end{aligned}
$$

where $C$ is the average concentration of the pollutant, $\left[C_{\text {low }}, C_{\text {high }}\right]$ are the concentration range boundaries from Table 2 within which $C$ falls in, $\left[I_{\text {low, }} I_{\text {high }}\right]$ is the corresponding range of $A Q I$ values. The integral index $\mathrm{AQI}^{*}$ is calculated as the maximum value for all pollutants $A Q l_{k}$, where $k$ is the pollutant number.

\subsection{Krasnoyarsk air quality monitoring network}

In Krasnoyarsk and its suburbs, there are seven automated monitoring posts (AMP) (Figure 1): 1-Vetluzhanka, 2-Pokrovka, 3-Solar, 4-North, 5-Cheryomushki, 6-Kubekovo, 7-Berezovka. The posts automatically measure mass concentrations of pollution in the air and record various meteorological parameters (wind direction and speed, temperature, relative humidity, atmospheric pressure) as well as collect, process and transmit the accumulated information to a remote server. The set of parameters measured at different AMPs differs, however, most of them transmit data on such pollutants as nitrogen oxide, nitrogen dioxide, sulfur dioxide, carbon monoxide, $\mathrm{PM}_{2.5}$. The acquired data are supplied to the Regional departmental information and analytical system on the state of the environment of the Krasnoyarsk territory (RDIAS) (CIEM 2019). The contours of height in Figure 1 show that the city is in a hollow.

The Institute of Computational Modeling (ICM SB RAS) also conducts research and development of software and hardware for atmospheric pollution monitoring. A research monitoring unit has been developed based on the geoportal software and technology platform (Shaparev and Yakubailik 2016; Shaparev et al. 2018; Yakubailik et al. 2018). The system provides data collection from external sources, data storage and aggregation, automatic calculation of derived indicators, uploading and presentation of data through a web interface. Data sources can be either individual sensors or external data-

\begin{tabular}{|c|c|c|c|c|c|c|c|c|c|}
\hline \multicolumn{2}{|c|}{$\begin{array}{c}\mathrm{O}_{3} \\
(\mathrm{ppb})\end{array}$} & \multirow{2}{*}{$\begin{array}{c}\mathrm{PM}_{2.5} \\
\left(\mu \mathrm{g} / \mathrm{m}^{3}\right)\end{array}$} & \multirow{2}{*}{$\begin{array}{c}\begin{array}{c}\mathrm{PM}_{10} \\
\left(\mu \mathrm{g} / \mathrm{m}^{3}\right)\end{array} \\
24 \mathrm{hr}\end{array}$} & \multirow{2}{*}{$\begin{array}{c}\begin{array}{c}\mathrm{CO} \\
(\mathrm{ppm})\end{array} \\
8 \mathrm{hr}\end{array}$} & \multicolumn{2}{|c|}{$\begin{array}{l}\mathrm{SO}_{2} \\
(\mathrm{ppb})\end{array}$} & \multirow{2}{*}{$\begin{array}{c}\mathrm{NO}_{2} \\
(\mathrm{ppb})\end{array}$} & \multirow{2}{*}{\multicolumn{2}{|c|}{ AQI }} \\
\hline $8 \mathrm{hr}$ & $1 \mathrm{hr}$ & & & & $1 \mathrm{hr}$ & $24 \mathrm{hr}$ & & & \\
\hline \multicolumn{8}{|c|}{$C_{\text {low }}-C_{\text {high }}$ (avg) } & $I_{\text {low }}-I_{\text {high }}$ & Category \\
\hline $0-54$ & - & $0.0-12.0$ & $0-54$ & $0.0-4.4$ & $0-35$ & - & $0-53$ & $0-50$ & Good \\
\hline $55-70$ & - & $12.1-35.4$ & $55-154$ & $4.5-9.4$ & $36-75$ & - & $54-100$ & $51-100$ & Moderate \\
\hline $71-85$ & $125-164$ & $35.5-55.4$ & $155-254$ & $9.5-12.4$ & $76-185$ & - & $101-360$ & $101-150$ & $\begin{array}{l}\text { Unhealthy for } \\
\text { Sensitive Groups }\end{array}$ \\
\hline $86-105$ & $165-204$ & $55.5-150.4$ & $255-354$ & $12.5-15.4$ & $186-304$ & - & $361-649$ & $151-200$ & Unhealthy \\
\hline $106-200$ & $205-404$ & $150.5-250.4$ & $355-424$ & $15.5-30.4$ & - & $305-604$ & $650-1249$ & $201-300$ & Very Unhealthy \\
\hline- & $405-504$ & $250.5-350.4$ & $425-504$ & $30.5-40.4$ & - & $605-804$ & $1250-1649$ & $301-400$ & Hazardous \\
\hline- & $505-604$ & $350.5-500.4$ & $505-604$ & $40.5-50.4$ & - & $805-1004$ & $1650-2049$ & $401-500$ & \\
\hline
\end{tabular}
bases or information systems through additional

Table 2. Conversion factors for individual pollutants (EPA 2018). 


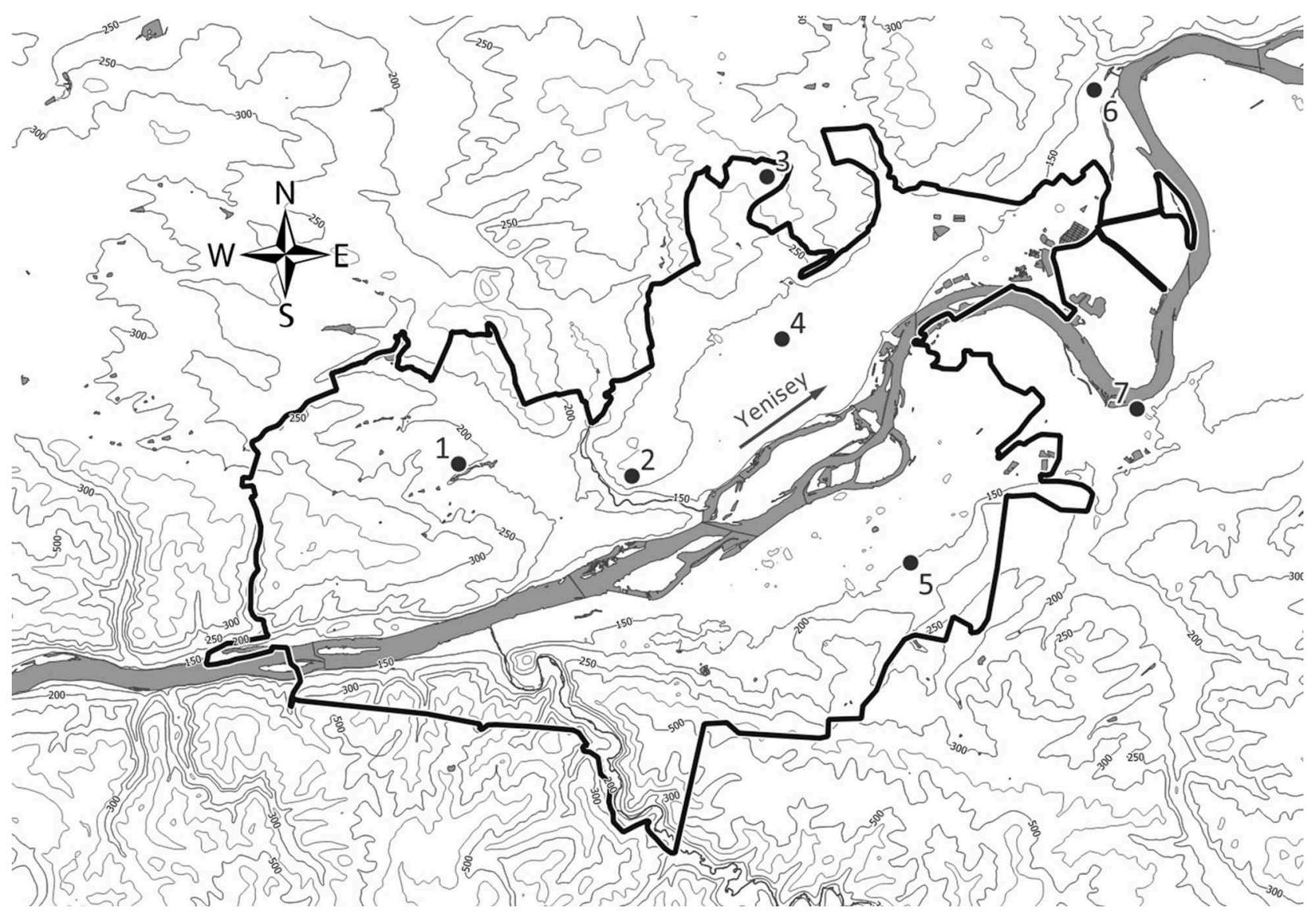

Figure 1. Air quality monitoring network in Krasnoyarsk and its neighborhoods.

adapters. Application programming interface (API) for integration with external information systems is supported. A software module has been developed for regular downloading of data from monitoring posts from the RDIAS system via a specialized web service. The geoportal features and software tools simplify the processing and analysis of the monitoring data.

\section{Results}

\subsection{Indicators of input influence}

\subsubsection{Analysis of pollutant emissions by UN indicators}

Initial data on the volume of emission of pollutants into the air of Krasnoyarsk were borrowed from the State reports on the state of the environment (MEEM 2008-2018).

The gross volume of pollutants is a total characteristic of the amount of pollution entering the atmosphere of the city per year. Figure 2 shows the change in gross emissions from stationary and mobile sources, as well as their total value, in the air environment of Krasnoyarsk over 2007-2017. Since 2013, the methodology for estimating emissions into the air from road transport has been amended, which resulted in a decrease in the estimates by almost 50\% (Order 2013).

From 2007 to 2017, gross emissions from stationary sources kept on reducing by about 4 tonnes per year. Emissions from road transport were growing by about

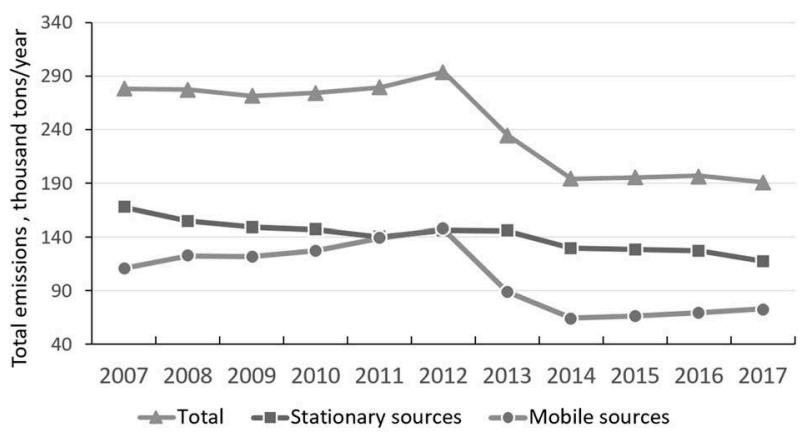

Figure 2. Gross emissions of pollutants into the atmosphere of Krasnoyarsk.

3 tonnes per year. In 2017, the contribution from mobile sources to total emissions was about $38 \%$.

Table 3 presents the structure of emissions of various pollutants in the atmosphere of Krasnoyarsk from stationary sources over the years 2007-2017. Both the gross value of emissions and the value per person are shown. Carbon monoxide accounts for about $50 \%$ of emissions. Emissions of nitrogen oxides remain at approximately the same level during the period under review.

\subsection{Conditions indicator}

\subsubsection{Analysis of atmospheric pollution index}

Table 4 shows the dynamics of changes in the annual indices of atmospheric pollution in Krasnoyarsk (MEEM 
Table 3. Dynamics and structure of emissions of various pollutants from stationary sources.

\begin{tabular}{|c|c|c|c|c|c|c|c|c|c|c|c|}
\hline \multirow[b]{2}{*}{ Year } & \multirow[b]{2}{*}{ Population $\left({ }^{*} 10^{3}\right)$} & \multirow[b]{2}{*}{ Total Emission (tonnes/year) } & \multicolumn{4}{|c|}{ Emission (tons/year) } & \multirow[b]{2}{*}{ Total Emission (kg/person/year) } & \multicolumn{4}{|c|}{ Emission (kg/person/year) } \\
\hline & & & Solids & $\mathrm{SO}_{\mathrm{x}}$ & $\mathrm{CO}$ & $\mathrm{NO}_{\mathrm{x}}$ & & Solids & $\mathrm{SO}_{\mathrm{x}}$ & $\mathrm{CO}$ & $\mathrm{NO}_{\mathrm{x}}$ \\
\hline 2007 & 932.5 & 163.9 & 34.3 & 28.0 & 83.0 & 15.5 & 175.8 & 36.8 & 30.0 & 89.0 & 16.6 \\
\hline 2008 & 948.5 & 150.4 & 29.0 & 28.5 & 74.4 & 15.6 & 158.6 & 30.5 & 30.1 & 78.4 & 16.4 \\
\hline 2009 & 963.2 & 149.3 & 27.4 & 28.2 & 72.5 & 16.4 & 155.0 & 28.4 & 29.2 & 75.3 & 17.0 \\
\hline 2010 & 979.6 & 147.1 & 26.7 & 28.4 & 71.1 & 16.2 & 150.1 & 27.2 & 29.0 & 72.6 & 16.6 \\
\hline 2011 & 979.6 & 140.1 & 24.9 & 25.9 & 70.3 & 14.8 & 143.0 & 25.4 & 26.4 & 71.7 & 15.1 \\
\hline 2012 & 1017.2 & 146.3 & 26.0 & 29.9 & 69.8 & 16.4 & 143.8 & 25.6 & 29.4 & 68.6 & 16.1 \\
\hline 2013 & 1036.6 & 145.6 & 22.1 & 27.1 & 69.1 & 23.6 & 140.5 & 21.3 & 26.1 & 66.7 & 22.7 \\
\hline 2014 & 1053.2 & 129.8 & 20.0 & 26.3 & 65.4 & 14.1 & 123.3 & 19.0 & 25.0 & 62.1 & 13.4 \\
\hline 2015 & 1066.9 & 128.7 & 20.1 & 26.7 & 62.5 & 14.6 & 120.6 & 18.8 & 25.0 & 58.6 & 13.7 \\
\hline 2016 & 1082.9 & 127.3 & 19.6 & 25.4 & 61.3 & 17.8 & 117.6 & 18.1 & 23.5 & 56.6 & 16.4 \\
\hline 2017 & 1090.8 & 117.6 & 17.3 & 22.7 & 58.8 & 16.5 & 107.8 & 15.9 & 20.8 & 53.9 & 15.1 \\
\hline
\end{tabular}

Table 4. Dynamics of annual indices of atmospheric pollution.

\begin{tabular}{cclccc}
\hline Year & API-5 & \multicolumn{1}{c}{ Pollutants } & $\mathrm{SI}$ & $\mathrm{HR}(\%)$ & Pollution level \\
\hline 2007 & 14.66 & $\mathrm{BP}, \mathrm{F}, \mathrm{PM}, \mathrm{NO}_{2}$ & 12.8 & 27.7 & very high \\
2008 & 15.31 & $\mathrm{BP}, \mathrm{F}, \mathrm{PM}, \mathrm{NO}_{2}, \mathrm{NO}$ & 18 & 23.3 & very high \\
2009 & 18.56 & $\mathrm{BP}, \mathrm{F}, \mathrm{PM}$ & 10.4 & 15.2 & very high \\
2010 & 21.86 & $\mathrm{BP}, \mathrm{F}, \mathrm{PM}, \mathrm{NO}_{2}$ & 20.4 & 23.2 & very high \\
2011 & 23.75 & $\mathrm{BP}, \mathrm{F}, \mathrm{PM}, \mathrm{NO}_{2}, \mathrm{NH}_{3}$ & 20 & 27.7 & very high \\
2012 & 22.93 & $\mathrm{~F}, \mathrm{BP}, \mathrm{PM}, \mathrm{NO}_{2}$ & 17 & 29 & very high \\
2013 & 17.05 & $\mathrm{~F}, \mathrm{BP}, \mathrm{PM}, \mathrm{NO}_{2}$ & 17.1 & 22.9 & very high \\
2014 & 17.48 & $\mathrm{~F}, \mathrm{BP}, \mathrm{EB}$ & 30.2 & 8.1 & very high \\
2015 & $>7$ & $\mathrm{~F}, \mathrm{BP}, \mathrm{PM}, \mathrm{NO}_{2}, \mathrm{NO}$ & 18.5 & 18 & high \\
2016 & $>14$ & $\mathrm{BP}, \mathrm{F}, \mathrm{NH}_{3}, \mathrm{NO}_{2}, \mathrm{PM}$ & 40.6 & 21.9 & very high \\
2017 & $>14$ & $\mathrm{BP}, \mathrm{F}, \mathrm{NH}_{3}, \mathrm{NO}_{2}, \mathrm{PM}$ & 20.1 & 23.1 & very high \\
\hline
\end{tabular}

2008-2018): API-5 - the integrated indicator of air pollution for five priority pollutants for the city; Pollutants: BP benz(a)pyrene, $\mathrm{F}$ - formaldehyde, $\mathrm{PM}$ - particulate matter, $\mathrm{NO}_{2}$ - nitrogen dioxide, $\mathrm{NH}_{3}$ - ammonia, $\mathrm{EB}$ - ethylbenzene; SI (Standard Index) - the highest measured single pollutant concentration divided by the MPC according to the measurement data of all pollutants in the city for the year; HR - the highest repeatability of exceeding the MPC from the measurement data at all observation stations for all determined impurities; Pollution level a qualitative characteristic of the pollution level.

It is important to note that the sharp decline in the air pollution estimates in 2014 was due to the change in the formaldehyde $M P C_{A D}$ (Order 2014).

During the period under review, the level of pollution remains consistently very high. The main pollutants affecting the values of the complex pollution index are benz(a)pyrene and formaldehyde.

\subsubsection{Air quality index analysis}

For AQI calculations, data on the level of atmospheric pollution from automated monitoring posts of the RDIAS system were used. The initial data set has a number of specific features: there are no data on Ozone and $\mathrm{PM}_{10}$; records on $\mathrm{PM}_{2.5}$ measurements are available only since the end of 2017; and there are gaps in the data.

The full year 2018 was chosen for the analysis. The AQI calculation method uses hourly data, so the raw data coming in with a period of 20 min were averaged for each hour. Since we estimate the influence of individual components in the integrated index, only those hours were selected that had data available for the most substances - $\mathrm{PM}_{2.5}, \mathrm{NO}_{2}, \mathrm{CO}, \mathrm{SO}_{2}$. The lack of data on $\mathrm{PM}_{10}$ is compensated by the data on $\mathrm{PM}_{2.5}$, as they correlate and the impact of the latter on human health is more significant (WHO 2006). To assess the state of the city's atmosphere as a whole, the values were averaged over all monitoring posts.

The result of processing is presented in Table 5, where $A Q I^{*}$ is the average $A Q I$ by month and for the year as a whole; AQI Components are the average $\mathrm{AQI}$ values for each pollutant; Influence of components is the percentage of time when the relevant pollutant was decisive for calculating the full air quality index; Hours is the number of hours for which data are available for all pollutants.

The data obtained show that the major influence on the Air Quality Index is usually from pollution by

Table 5. Average AQI and impact of individual components over the year 2018.

\begin{tabular}{|c|c|c|c|c|c|c|c|c|c|c|}
\hline \multirow[b]{2}{*}{ Month } & \multirow[b]{2}{*}{$A Q I^{*}$} & \multicolumn{4}{|c|}{ AQI Components } & \multicolumn{4}{|c|}{ Influence of components, \% } & \multirow[b]{2}{*}{ Hours } \\
\hline & & $\mathrm{PM}_{2.5}$ & $\mathrm{NO}_{2}$ & $\mathrm{CO}$ & $\mathrm{SO}_{2}$ & $\mathrm{PM}_{2.5}$ & $\mathrm{NO}_{2}$ & $\mathrm{CO}$ & $\mathrm{SO}_{2}$ & \\
\hline January & 94.6 & 94.5 & 20.0 & 5.4 & 8.4 & 99.5 & 0.4 & 0 & 0.1 & 2280 \\
\hline February & 118.1 & 117.8 & 31.0 & 7.3 & 9.0 & 99.2 & 0 & 0 & 0.8 & 2381 \\
\hline March & 80.7 & 78.2 & 29.6 & 4.2 & 7.7 & 91.0 & 8.8 & 0.1 & 0.4 & 2619 \\
\hline April & 50.9 & 49.5 & 18.6 & 2.4 & 6.3 & 92.8 & 7.2 & 0 & 0.3 & 2722 \\
\hline May & 38.8 & 37.8 & 11.8 & 2.3 & 8.6 & 94.2 & 2.8 & 0 & 3.4 & 2855 \\
\hline June & 66.1 & 66.0 & 14.1 & 2.9 & 8.4 & 99.2 & 0.8 & 0 & 0 & 2443 \\
\hline July & 84.5 & 84.2 & 13.9 & 3.7 & 2.9 & 98.7 & 1.4 & 0 & 0 & 2286 \\
\hline August & 54.4 & 53.0 & 16.0 & 3.4 & 5.1 & 93.3 & 6.9 & 0 & 0.1 & 3405 \\
\hline September & 53.7 & 50.5 & 23.3 & 4.4 & 4.0 & 85.5 & 14.8 & 0 & 0.3 & 2286 \\
\hline October & 61.3 & 56.4 & 29.3 & 5.9 & 6.5 & 81.7 & 18.8 & 0 & 0.2 & 2534 \\
\hline November & 57.9 & 53.9 & 23.3 & 6.0 & 7.8 & 76.3 & 20.7 & 0 & 4.0 & 3071 \\
\hline December & 85.9 & 79.4 & 36.8 & 7.8 & 9.3 & 80.8 & 19.5 & 0 & 0.1 & 2131 \\
\hline 2018 overall & 68.9 & 66.8 & 21.9 & 4.5 & 7.0 & 90.9 & 8.6 & 0 & 0.9 & 31013 \\
\hline
\end{tabular}


particulate matter $-91 \%$. A small contribution is made by nitrogen dioxide - about $8.6 \%$, and sulfur dioxide - less than $1 \%$.

\subsubsection{Dependence of $A Q I$ on weather conditions}

4.2.3.1. Statistical data. According to Table 5, particulate matter (PM) is the main pollutant contributing to the air quality index in Krasnoyarsk. Note also that at $A Q I>100$, according to Table 2, unfavorable conditions occur for sensitive people (Unhealthy for Sensitive Groups), and at AQI>150 - for the entire population (Unhealthy). Therefore, we will consider the value $A Q I>100$ to be critical. According to Figure 3, the critical AQI values are observed mostly in the winter period.

We performed a statistical analysis of the dependence of $A Q \mathrm{I}$ on the wind speed, wind direction, atmospheric pressure, relative humidity and air temperature. Figures 4 and 5 present data for 2018 reflecting statistical dependence between AQI (ordinate axis) and the weather conditions (abscissa axis). Each point shows an average value of the indicators for a single hour in the year.

Analysis of the statistical data shows that the critical values of $\mathrm{AQ}$ set in under the following circumstances:

- Wind speeds of less than $1 \mathrm{~m} / \mathrm{s}$.

- North-East, East and South-East wind directions.

- Air temperatures from $-10^{\circ} \mathrm{C}$ to $-35^{\circ} \mathrm{C}$ and $10^{\circ} \mathrm{C}$ to $30^{\circ} \mathrm{C}$.

- Atmospheric pressure from 750 to $770 \mathrm{~mm} \mathrm{Hg}$.

- Relative humidity in the range of $70-80 \%$.
4.2.3.2. Dynamic data. Consider the temporal characteristics of weather conditions, leading to critical AQI values in different seasons.

4.2.3.2.1. Winter. The critical $A Q I$ values are caused by an increase in pressure up to $770 \mathrm{~mm} \mathrm{Hg}$, temperature decrease down to $-30^{\circ} \mathrm{C}$ and the presence of the south-east wind. If the wind changes to the south-west, the AQI values decrease. As the pressure drops and the temperature rises, the AQI values go down. Such weather conditions are due to the fact that in winter Krasnoyarsk as a rule is influenced by the Siberian anticyclone with its center located in Mongolia. In the anticyclone region, downward air flows predominate to result in a higher pressure and lower temperature near the land surface. During this period, the smoke from pipes cannot overcome the descending cold masses, which leads to the formation of smog. At lower temperatures, one has to increase fuel burning, which further aggravates the situation. Anticyclone does not allow water vapor to rise up and forms a clear windless weather and frosts. However, the smog disappears as soon as the wind from the south-west gets stronger (Figure 6). Due to the climate changes, the Siberian anticyclone is actively developing and in winter in Krasnoyarsk the critical AQI values are observed more and more often.

4.2.3.2.2. Spring. In early March, a critical state of AQI was developing due to the abatement of the wind. However, later on the wind speed increased and its direction changed to the south-west, which reduced the values of $A Q I$.

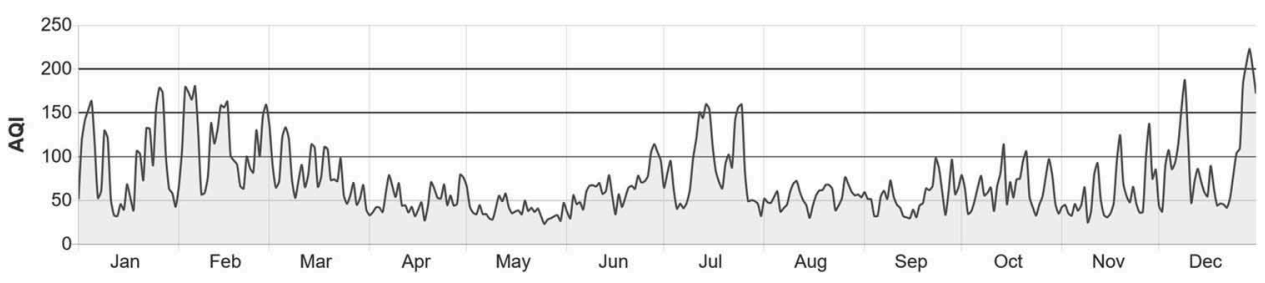

Figure 3. AQI values for 2018 averaged over all monitoring posts.

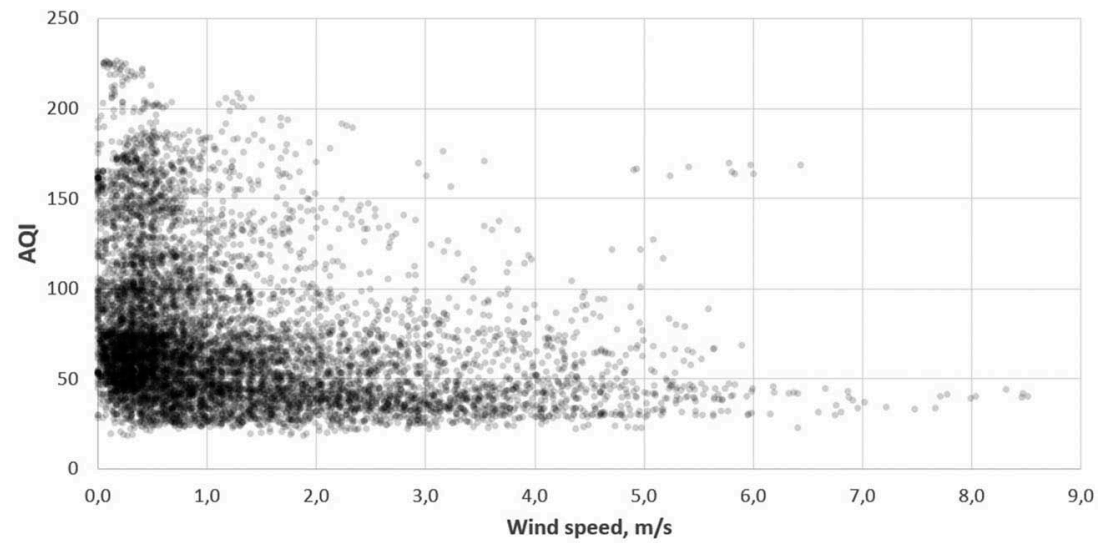

Figure 4. AQI scatter plot versus wind speed. 

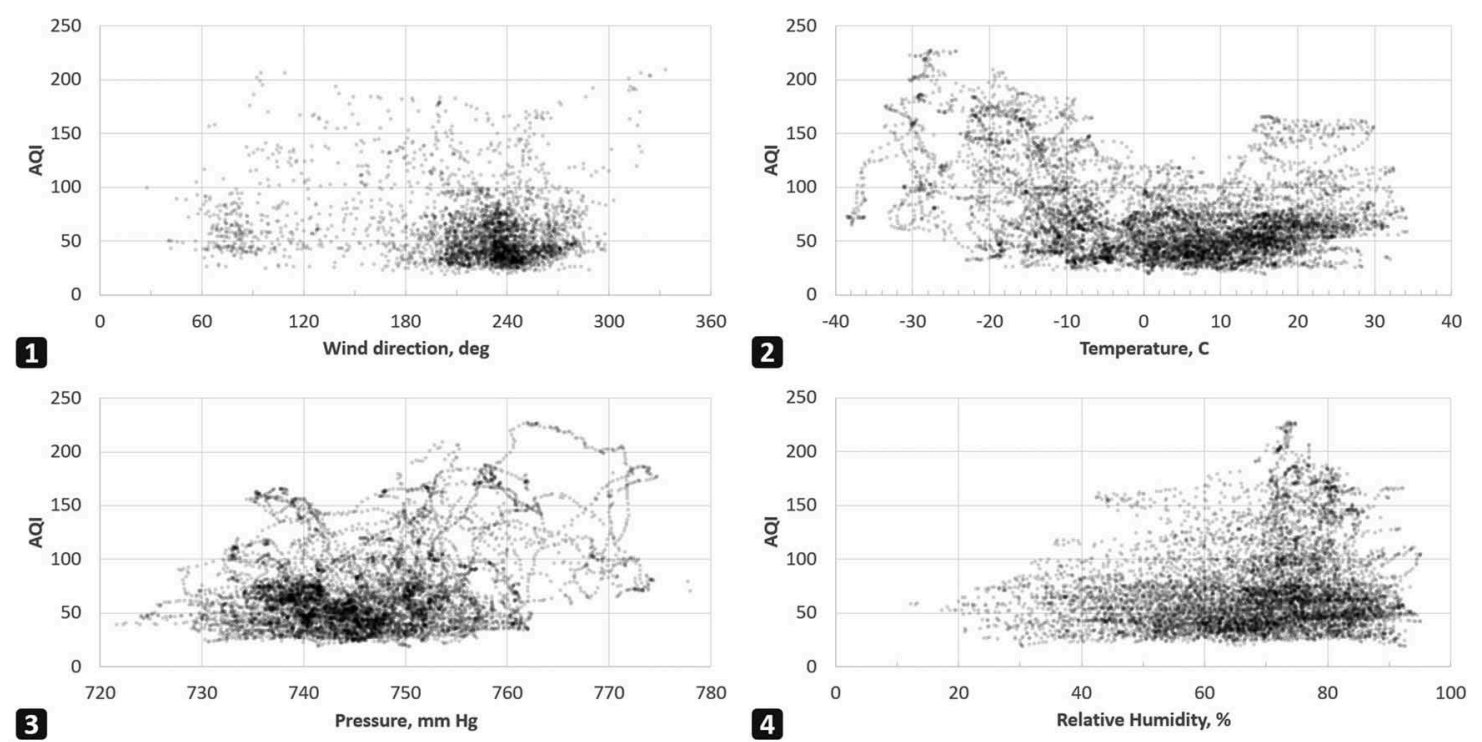

Figure 5. AQI scatter plot versus wind direction (1), air temperature (2), atmospheric pressure (3), relative humidity (4).

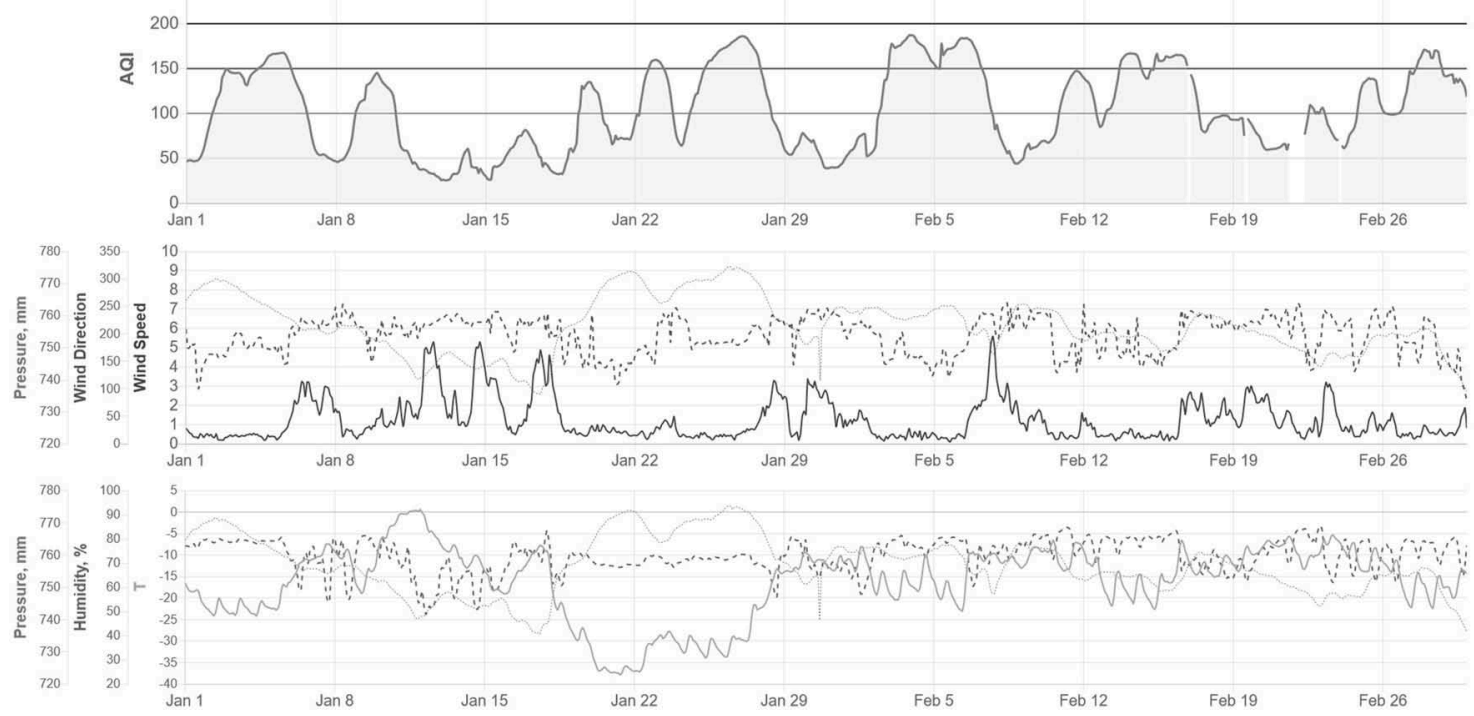

Figure 6. AQI values and weather data averaged over all observation posts (winter).

4.2.3.2.3. Summer. In late June, due to the east wind the value of $A Q I$ began to increase, but change of the wind direction to the south-west brought it back down. In mid-July, AQI reached its critical value. This was caused by the south-east wind, which did not allow the suspended particles to leave the basin. Later on, the wind changed its direction to the southwest and the value of $\mathrm{AQI}$ decreased.

\subsection{Management indicator}

The government of the Russian Federation has approved a comprehensive action policy to reduce emissions of pollutants into the air within the framework of the Federal project 'Clean Air' of the National project 'Ecology' (EcoPassport 2018). Under this policy, the total amount of financing allocated for implementing the plan in Krasnoyarsk is 68.7 billion rubles
(\$1 billion). Of these, almost 20 billion rubles (\$308 million) are to be spent on measures to reduce emissions from transport, 1.7 billion rubles (\$26 million) to modernize industrial enterprises, and 46.5 billion rubles ( $\$ 715$ million) will be spent on reducing emissions from heat and power generating enterprises and the private sector. The comprehensive policy involves demolition of dilapidated houses with furnace heating, replacement of inefficient coal-fired boilers, improvement of the monitoring system of atmospheric air, regional environmental supervision, and creation of a green belt of forests and parks in the city area. According to the program, by 2024 the volume of pollutant emissions in Krasnoyarsk is to be reduced by $22.3 \%$ (or 42.58 thousand tonnes).

However, the key to improving the air quality in Krasnoyarsk is transition from coal fuel to gas. A Master plan for gas supply and gasification of the 
region (EnergoPassport 2019) has been agreed upon in the Krasnoyarsk territory. Three possible scenarios are considered: the first one involves construction of a pipeline from the local oil fields in the Krasnoyarsk region itself ( 83.8 billion rubles or $\$ 1.3$ billion); under the second and third scenarios the pipelines are to be fed from the pipeline systems of the Tomsk (52.1 billion rubles or $\$ 800$ million) and Kemerovo (48.8 billion rubles or $\$ 750$ million) regions, respectively. However, until 2023, only preparatory measures are to be implemented.

\section{Conclusions}

The paper presents the state of the atmosphere of Krasnoyarsk (Russia) in terms of sustainable development. For this purpose, we have used indicators adopted by the UN, developed in Russia and the United States. The indicators include Input Influence, Conditions, and Management. The state analysis is based on data from the State reports 'On the condition and protection of the environment in the Krasnoyarsk region' for 2007-2017 years and the results obtained from the regional environmental monitoring system RDIAS.

According to the gross indicators, the level of air pollution over 2014-2017 has slightly reduced but still remains consistently high compared to other cities in Russia. The decrease is due to the improvement of dust and gas cleaning systems at large industrial enterprises. Gross emissions in 2017 amounted to $62 \%$ from stationary sources and $38 \%$ from mobile sources. The structure of emissions of various substances in 2017 from stationary sources was as follows: carbon monoxide $-50 \%$, sulfur dioxide $-19.3 \%$, matter $-14.7 \%$, nitrogen oxides $-14 \%$. It should be noted that specific emissions per person for all pollutants were decreasing during 2007-2017.

It has been shown that the value of the integrated indicator API-5 is mainly determined by benz(a)pyrene and formaldehyde and remains consistently very high. The determining component in the formation of AQI for the city of Krasnoyarsk is particulate matter. We have been able to relate the critical $A Q I$ values to certain adverse weather conditions, including the absence of wind or its blowing in the north-east or south-east direction, the formation of an anticyclone in winter and a temperature inversion layer in the atmosphere in summer.

\section{Disclosure statement}

No potential conflict of interest was reported by the authors.

\section{ORCID}

N. Shaparev (D) http://orcid.org/0000-0003-2464-9587

A. Tokarev (D) http://orcid.org/0000-0002-9997-9065

O. Yakubailik (D) http://orcid.org/0000-0002-2668-4776

\section{References}

[EcoPassport] 'Passport of the National project 'Ecology'. 2018. (approved by the presidium of the presidential council of rf on strategic development and national projects, protocol of 24.12.2018 No 16).

[EnergoPassport] Passport of the state programme 'Energy efficiency and development of power engineering'. 2018. [Internet]. [accessed 2019 Sept 30]. http://www.krskstate. ru/government/gosprogrammy/0/id/32037.

Bell JNB, Power SA, Jarraud N, Agrawal M, Davies C. 2011. The effects of air pollution on urban ecosystems and agriculture. Int J Sustain Dev World Ecol. 18(3):226-235. doi:10.1080/13504509.2011.570803.

Bell ML, Davis DL, Fletcher T. 2004. A retrospective assessment of mortality from the London smog episode of 1952: the role of influenza and pollution. Environ Health Perspect. 112(1):6-8.

EPA. 2018. Technical assistance document for the reporting of daily air quality - the Air Quality Index (AQI). U.S. Environmental Protection Agency (NC). [accessed 2019 Sept 30]. https://www3.epa.gov/airnow/aqi-technicalassistance-document-sept2018.pdf.

Hu JL. 2006. Efficient air pollution abatement for regions in China. Int J Sustain Dev World Ecol. 13(4):327-340. doi:10.1080/13504500609469684.

Lavee D. 2018. Cost-benefit analysis of implementing policy measures for reducing PM and $\mathrm{O} 3$ concentrations: the case of Israel. Int J Sustain Dev World Ecol. 25 (8):683-695. doi:10.1080/13504509.2018.1466210.

[CIEM] Center for the implementation of environmental management and environmental protection in the Krasnoyarsk Territory. Subsystem for monitoring air pollution. 2012. [accessed 2019 Sept 30]. http://krasecology.ru/Air.

[RD]. 1991. Guidelines on the control of atmospheric pollution RD 52.04.186-89. L.: Gidrometeoizdat.

Niu Z, Chen J, Xu L, Yin L, Zhang F. 2013. Application of the environmental internet of things on monitoring PM2.5 at a coastal site in the urbanizing region of southeast China. Int J Sustain Dev World Ecol. 20(3):231-237. doi:10.1080/ 13504509.2013.782904.

Order. 2013. Order of the Federal Service for the Supervision of Natural Resources of November 1, 2013 No. 6-p 'On approval of the procedure for organizing work on the assessment of emissions from certain types of mobile sources'.

Order. 2014. Decree of the Chief state sanitary physician of RF of April 7, 2014, No 27 'On introducing amendment No 10 into GN2.1.6.1338-03 'Maximum permissible concentrations (MPC) of pollutants in the atmospheric air of populated areas'.

Shaparev N, Astafiev N. 2008. Water resources of the Krasnoyarsk Krai in sustainable water management indices. Int J Sustain Dev World Ecol. 15(6):574-583.

Shaparev N, Tokarev A, Yakubailik O, Soldatov A. 2018. Web technologies for rapid assessment of pollution of the atmosphere of the industrial city. IOP Conf Series. 363:012034.

[UN] United Nations. 1996. Indicators of sustainable development framework and methodologies. New York: United Nations; p. 359.

[MEEM] Ministry of Ecology and Environmental Management of the Krasnoyarsk Territory. 2008-2018. State reports 'On the state and protection of the environment in the Krasnoyarsk Territory for 2007-2017'. Krasnoyarsk.

[SR] State report. 2018. 'On the state and protection of the environment of the Russian Federation in 2017'. M.: Minprirody of Russia, NPP 'Cadaster'. 
Shaparev N, Yakubailik O. 2016. Usage of web mapping systems and services for information support of regional management. MATEC Web Conf. 79:01081.

Shi L, Zhang M, Yang B, Gao L. 2018. Air pollution-oriented ecological risk assessment in Xiamen city, China. Int J Sustain Dev World Ecol. 25(5):420-430. doi:10.1080/ 13504509.2017.1419390.

WHO. 2006. Air quality guidelines for particulate matter, ozone, nitrogen dioxide and sulfur dioxide. global update 2005: summary of risk assessment. WHO: Geneva.
WHO. 2009. Global health risks. World Health Organization: Geneva.

WHO. 2014. Burden of disease from the joint effects of household and ambient air pollution for 2012. WHO:Geneva.

Yakubailik OE, Kadochnikov AA, Tokarev AV. 2018. WEB Geographic Information System and the Hardware and Software Ensuring Rapid Assessment of Air Pollution. Optoelectron Instrum Data Process. 54(3):243-249.

Zvyagintev AM, Kuznetsova IN, Tarasova OAShalygina IY. 2014. Variability of concentration of major air pollutants in Iondon'. Atmos Ocean Opt. 27(5):424-434. 